\title{
Law and Habits
}

\author{
Sylvie Delacroix ${ }^{1}$ \\ UCL Laws
}

'[T]he horrible thing about all legal officials, even the best, about all judges, magistrates, barristers, detectives, and policemen, is not that they are wicked (some of them are good), not that they are stupid (several of them are quite intelligent), it is simply that they have got used to it. Strictly they do not see the prisoner in the dock; all they see is the usual man in the usual place. They do not see the awful court of judgment; they only see their own workshop.' (G.K. Chesterton, On tremendous trifles ${ }^{2}$ )

We have all been there: to fail to 'see' beyond routine appearances and hence grasp the moral salience of a situation is easy. It is made easier still when that situation is structured around a normative framework that defines the roles of its protagonists. That normative framework need not be legal. It may be professional, conventional or otherwise. Yet because of the pervasive reach and specific nature of its institutional structure, a legal framework may well be uniquely conducive to the 'rote blindness' described above.

\footnotetext{
${ }^{1}$ The work leading to this paper was funded by the Leverhulme Trust. I am grateful for the comments and insights of Simon Blackburn, Clare Carlisle, Sean Coyle, Maks Del Mar, Jakob Holterman, Jonathan Montgomery, Georgios Pavlakos, Dan Priel, Andrea Sangiovanni, Philip Schofield, Kevin Toh, Michael Wilkinson, Lorenzo Zucca and, last but not least, the editor of this Journal.

${ }^{2}$ G. K. Chesterton, 'The Twelve Men', Tremendous Trifles (Tremendous Trifles, Sheed \& Ward 1955)
} 
This peril is indirectly related to a concern which Hart formulates differently when he refers to the 'risk that the centrally organised power may well be used for the oppression of numbers with whose support it can dispense, in a way that the simpler regime of primary rules could not' ${ }^{3}$ Hart's worry works like this: one of the defining features of established legal orders is that they can be sustained on the basis of official acceptance alone, thanks to their institutional structure (thesis 1). Because of this structure, it may well be the case that an established legal system (as opposed to a simpler regime of primary rules) is particularly conducive to a society that is 'deplorably sheeplike' -and where the sheep might all end up 'in the slaughterhouse ${ }^{\prime 4}$ (thesis 2 ). This article argues that thesis 2 is correct and deserves greater attention. ${ }^{5}$ This is in part due to the fact that it is muddled by its association with thesis 1 , which is unhelpful at best, and not only because of the minimalist way in which Hart defines acceptance.

'An unreflecting inherited or traditional attitude, or the mere wish to do as others $\mathrm{do}^{\prime 6}$ clearly offers little safeguard against the ‘sheeplike' predicament Hart worries about. To make sense of the risk inherent in the emergence of law's complex institutional structure, one needs to turn upstream, to the complex web of social processes that shape and enable the attitudes encompassed under Hart's concept of 'acceptance'. While considerable work has already been devoted to delineating the ways in which 'practices' (conventional or otherwise ${ }^{7}$ ) may give rise to legal norms,

\footnotetext{
${ }^{3}$ H. L. A. Hart, The concept of law (2nd edn, Clarendon Press 1994) 202.

${ }^{4}$ Ibid.

${ }^{5}$ Both Jeremy Waldron, 'All We Like Sheep' (1999) 12 Can JL \& Jurisprudence 169) and Leslie Green, 'Positivism and the Inseparability of Law and Morals' (2008) 83 NYUL Rev 1035) have helped flag up this important aspect of Hart's theory, but have mostly considered it in the wider context of law's separability from morality. This article seeks to refine our understanding of the factors that contribute to the 'sheeplike' quality of behavior that is facilitated by (in contrast to that which generates) legal institutions.

${ }^{6}$ Hart, The concept of law.

7 Andrei Marmor, 'Legal conventionalism' in Jules Coleman (ed), Hart's Postscript, essays on the Postscript to the Concept of Law (Hart's Postscript, essays on the Postscript to the Concept of Law, Oxford University Press 2001)Gerald J. Postema, 'Coordination and convention at the foundations of law' (1982) 11 Journal of legal studies 165Gerald J. Postema, 'Norms, reasons and law' (1998) 51 Current legal problems 149Michael E Bratman, 'Shared cooperative activity' (1992) 101 The philosophical review 327.
} 
far less attention has so far been paid to the patterns of repeated behavior -habitsthat feed such practices. Most legal theorists will tell you that there is a good reason for such scant developments, for everybody knows that `habits are not the [...] sort of things that can impose obligations ${ }^{\prime}{ }^{8}$

The first part of this article exposes the dualist meta-ethical presuppositions that lurk behind such an apparently unproblematic statement and delineates the contours of a (non-reductive) moral naturalism that gives a central place to habits. By throwing light on the full spectrum of habits (from 'mere' tics and automated behaviour to the reflective habits that constitute a particular kind of practice), this article emphasizes the qualitative difference between the habits that are capable of generating the practices at the heart of a legal system and the habits that this system's 'division of normative labour' is conducive to. Hart's 'thesis 2 ' is correct because and to the extent that law's institutional structure does facilitate the development of rigid habits, i.e. habits that have lost their adaptability and hence their ability to generate and support practices (conventional or otherwise).

The second part of this article starts with the intellectual roots of what could have been Hart's (non-reductive) naturalist account of legal normativity, whereby there would be no 'gap' between habits as social facts on the one hand and social rules on the other: a gap which Hart endeavours to bridge via his notion of acceptance. Section 2.2 unpacks the two-way relationship between habits and law while section 2.3 draws upon the latter to bolster Hart's claim that law is inherently conducive to a society that is 'deplorably sheeplike' (once this claim is rid of its association with 'official acceptance').

\footnotetext{
8 'Fortunately, plans are the right sort of things' (Scott J. Shapiro, 'Law, Plans, and Practical Reason' (2002) 8 Legal Theory 387 438).
} 


\section{The nature of habit and its relationship to ethical agency}

Habit requires repetition -whether it be repeated movement, or posture, or frame of thought. In the pattern shaped by this repetition, at some point a habit is formed. To try to identify a precise moment in time when a habit is born is doomed to failure, for diminished awareness of the pattern underlying it is key to its emergence. ${ }^{9}$ While one can intentionally seek to develop some habit, ${ }^{10}$ the latter is born only once the behavior, posture or frame of thought underlying it has become so internalized that it takes effort to bring it back to conscious awareness. Now just as this numbing of one's passive sensibility takes root, habit concomitantly buoys up whatever activity underlies it. When I get used to bicycling between cars in the morning rush hour, I not only become less tense when doing so; I also acquire some genuine dexterity.

It is this double effect of habit which Hume refers to when he emphasizes that 'custom increases [sic] all active habits, but diminishes passive, according to the observation of a late eminent philosopher [Butler] ${ }^{\prime 11}$ When they are considered specifically in the moral sphere, the active and passive aspects of habit make it a double-edged sword. While habituation is central to the processes by which we come to acquire a taste for - and our ease in discerning- standards of right and wrong, it is also what can stop us from waking up to the demands of such standards, lulled into a comforting but dangerous sense of routine.

\footnotetext{
${ }^{9}$ External observation necessarily comes too late.

${ }^{10}$ Habits can be acquired in many ways: intentionally (for instance to foster the realisation of a particular goal) or unintentionally (through upbringing or simply responding to particular environmental features that shape one's behaviour).

${ }^{11}$ David Hume, A Treatise on Human Nature (Oxford University Press 1978) 424. The 'late eminent philosopher' Hume is referring to is Bishop Butler, who emphasises what he calls 'the double effect of habit': 'From these two observations together, that practical habits are formed and strengthened by repeated acts; and that passive impressions, by being repeated upon us, grow weaker; it must follow, that active habits may be gradually forming and strengthening, by a course of acting on such and such motives and excitements, whilst these motives and excitements themselves are, by proportionate degrees, growing less sensible, i.e. are continually less and less sensibly felt, even as the active habits strengthen. And experience confirms this; for active principles, at the very time that they are less lively in perception than they were, are found to be, somehow, wrought more thoroughly into the temper and character, and become more effectual in influencing our practice.' (J. Butler, Analogy of religion, natural and revealed, to the constitution and course of nature (Bell and Daldy 1857) 108).
} 
'E]thics strives to legislate a world in which the good is done fluidly, as a matter of habituation, if not fact, even as it is recognized that the very thing ethics can never be is an acting that is merely habit or matter of fact. Even as ethics seeks to become familiar, it insists on rendering the world unfamiliar. The emergence of ethical obligation both insists on regularity in one's conduct and resists that regularity.'. ${ }^{12}$

Because habits' compelling force typically eludes us $^{13}$, they may be seen as a moral menace, surreptitiously compromising our autonomy. Hence, for many, `ethics can never be an acting that is merely habit' (see the above quotation): in her seminal work on habit ${ }^{14}$, Clare Carlisle traces a philosophical thread that links Kant to Kierkegaard and Bergson via less well-known authors such as Maine de Biran. For Carlisle, it is de Biran's ambivalence towards habit that makes his account particularly interesting. de Biran indeed deems habit to be the 'general cause of our progress on the one hand, of our blindness on the other'. ${ }^{15}$ Because habit can eclipse reflective thought, and because reflective thought is deemed (by those authors within the Kantian thread) to condition the exercise of our freedom, habit belongs firmly to the 'messy', causal, space of desires, inclinations and the like.

\footnotetext{
12 James Hatley, Janice McLane and Christian Diehm (eds), Interrogating ethics: embodying the good in Merleau-Ponty (Duquesne University Press 2006) 3.

13 ' [O]f all enemies, habit is perhaps the most cunning, and above all it is cunning enough never to let itself be seen, because the person who sees the habit is saved from the habit.' S. Kierkegaard, Works of Love (Princeton University Press 1995) 36.

${ }^{14} \mathrm{C}$. Carlisle, 'Creatures of habit: the problem and the practice of liberation' (2006) 38 Continental Philosophy Review 19, C. Carlisle, 'Between Freedom and Necessity : Felix Ravaisson on Habit and the Moral Life' (2010) 53 Inquiry 123, C. Carlisle, On habit (Routledge 2014).

${ }^{15}$ Pierre Maine De Biran, The influence of habit on the faculty of thinking, vol 3 (Williams \& Wilkins 1929) 49. Carlisle emphasises the extent to which de Biran's ambivalence towards habit is born out of the tensions underlying his metaphysics' dualist presuppositions: 'Biran's whole account of habit is characterised by tensions and inconsistencies that testify to a kind of struggle between reason and habit: on the one hand, there is the insistence on a dualistic psychology, and on the other hand the acknowledged failure clearly to separate activity and passivity, perception and sensation, the voluntary and the involuntary' (Carlisle, 'Between Freedom and Necessity : Felix Ravaisson on Habit and the Moral Life').
} 
Now, the metaphor of two spaces which typically underlies negative evaluations of habit is far from casual. In Kant it explicitly structures his assertion of the priority of freedom, 'so the space of reasons is the space in which our transcendental freedom operates, in spite of the deterministic course of the rest of our being [including habits]. ${ }^{16}$ In line with this dualist framework, theories of ethical development ${ }^{17}$ are traditionally structured around a gradual detachment from the emotional and habitual roots of ethical action, celebrating reflective reasoning -typically along Kantian lines- as the culmination of mature agency.

This emphasis on the necessity to grow out of the habitual through critical reasoning translates a key assumption that structures all non-naturalist accounts of ethical agency: there is a fundamental discontinuity between the natural and the ethical. While non-cognitivists draw from the gap between those two spaces their skepticism about the truth-aptitude of moral statements, Kantian accounts of ethical agency take that gap to condition the very possibility of asserting our ethical freedom (and concomitant responsibility). Kant indeed deemed habit -understood as mindless, automatic repetition, and thus firmly belonging to the space of causes- to be a sign of human enslavement:

\footnotetext{
${ }^{16}$ Simon Blackburn, 'Normativity a la mode' (2001) 5 Journal of Ethics: An International Philosophical Review 139140.

${ }^{17}$ Kohlberg's theory of ethical development is the most famous instantiation of that Kantian perspective in developmental psychology. When he developed his theory of moral stages in the 1950s, the dominant, 'socialization' view claimed that 'society is prior to the individual, both chronologically and morally. It is the source of all values, which are eventually reflected in the individual' (Melford Spiro, 'Culture and Personality: The Natural History of a False Dichotomy' (1951) 14 Psychiatry 19, p. 20). The essentially passive role attributed to the individual - seen as a value receptacle- by this socialization view worried Kohlberg. Aside from the danger of social stagnation, Kohlberg was acutely aware of the peril inherent in over-emphasising adequate adjustment to socially constituted habits of evaluation. For 'to identify morality with conformity is to be forced to take the position that a loyal Nazi was behaving morally' (Lawrence Kohlberg, 'Moral stages and moralization' in Thomas Lickona (ed), Moral development and behavior: Theory, research, and social issues (Moral development and behavior: Theory, research, and social issues, Holt, Rinehart and Winston 1976), p. 3.). Kohlberg's defining moral maturity by reference to the individual's capacity to 'differentiat[e] his self from the rules and expectations of others and defin[e] his values in terms of self-chosen principles' (ibidem, p.33) is a direct attempt to address this concern, yet it came at a price, as such a Kantian stand forced Kohlberg to belie the spirit of a pragmatist tradition he was clearly attracted to.
} 
'An aptitude (habitus) is a facility in acting and a subjective perfection of choice. But not every such facility is a free aptitude (habitus libertatis); for if it is a habit (assuetudo), that is, a uniformity in action that has become a necessity through frequent repetition, it is not one that proceeds from freedom, and therefore not a moral aptitude. ${ }^{18}$

This article problematizes the narrow Kantian understanding of habit as mindless repetition (which is still widely influential in legal theory today - see the quotation from Shapiro in the introduction) to highlight the wide range of ways of having a habit, and their significance for our understanding of legal normativity (and, concomitantly, for our understanding of the moral risks inherent in law's institutional structure -this normative aspect is discussed in 2.3).

Because the account of habit that emerges from this article stands in the way of any non-naturalist effort to preserve the 'gap' between '(mere) nature' and ethics, section 1.1. is devoted to delineating (in broad terms ${ }^{19}$ ) the type of naturalism that stems from this analysis of habit. Of the challenges such an account raises in committing to a naturalist methodology, none is more important than the task of explaining what, if anything, enables us to stand back from and to challenge the habitual, whether it be to ultimately trigger moral (and legal) change or not. This will be discussed in section 1.2.

\subsection{Growing within (rather than out of) the habitual: developing a non- reductive moral naturalism}

\footnotetext{
18 Kant, I. [1797] (1996) The Metaphysics of Morals, trans. M. Gregor (Cambridge: Cambridge University Press), ms. 6: 407).

${ }^{19}$ For a full account of the habit-centred naturalism hinted at in this article, see S. Delacroix, Habitual Ethics? (2018).
} 
The type of moral naturalism ${ }^{20}$ defended here, which gives a central place to habit, rejects both non-naturalism and any kind of naturalism that lets the current results of our natural sciences define what belongs to nature and what does not. As for the former, one may usefully distinguish between two broad types of non-naturalism. While 'subjectivists' highlight the man-made nature of the ethical realm to dismiss it as lacking in objectivity (compared to the natural realm), 'supernaturalist rationalists ${ }^{21}$ insist that at least some ethical values are independent from -and more objective than- natural facts.

Given the range of possible ways of defining -and articulating the relationship between- 'nature' and 'science' respectively, naturalism can come in many shapes and colours. Because of some versions' scientistic excesses, 'the tide of naturalism [which] has been rising since the seventeenth century' can be perceived as a threat: the regions under threat are some of the most central in human life.'22 To protect these 'regions' -morality is one of them- an increasing number of contemporary philosophers (from Price to Putnam via McDowell and Blackburn) find themselves 'on the same [broad or liberal] side of the barricades' ${ }^{23}$, even if their respective naturalisms differ in some important ways. For the purposes of this article, it is helpful to highlight three conceptual hurdles -defining 'the natural', 'science' and 'internalism about reasons', which usefully delineate the kind of naturalism at stake (and which a habit-centred naturalism faces more felicitously than others).

\footnotetext{
${ }^{20}$ Whatever else it is, naturalism involves at least one 'lowest common denominator' commitment. Its rejection of any dualist metaphysics involves a claim that 'there is no unbridgeable space between what happens in that [natural] order and any other order in heaven or earth, including the order of our own minds' (Blackburn, 'Normativity a la mode'). On this basis, the challenge which any naturalist account of morality must address consists in understanding how the demands and aspirations we characteristically associate with morality may be understood as outgrowths of our animal (rather than noumenal, or god-like etc.) nature: 'there must be no unmoved mover: no intervention of the divine spark, or gifts from unexplained quarters' (ibid.).

${ }^{21}$ I borrow this otherwise cumbersome term from McDowell as it has the merit of encompassing a wide range of positions, ranging from Platonism to intuitionism, via natural law theories (John McDowell, Mind, Value, and Reality (Harvard University Press 1998) 167).

${ }^{22}$ Huw Price, 'Naturalism and the fate of the M-Worlds' (1997) 7 Proceedings of the Aristotelian Society 247.

23 Paul Redding, 'Two directions for analytic Kantianism' in Mario De Caro and David Macarthur (eds), Naturalism and Normativity (Naturalism and Normativity, Columbia University Press 2010) 271.
} 


\subsection{1. 'The Natural'}

There cannot be any discontinuity between the ethical and the natural in an account of ethical agency that gives a central place to habit. And that is not because the ethical is 'merely' natural but rather because, as Hans Fink nicely puts it: 'Nature is never mere nature. That which is more than mere is nature, too' ${ }^{24}$ Habits (along with the historical, the aesthetical, the man-made) are among those things that are 'more than mere' nature. Dewey has a nice way of illustrating the sort of naturalism that is at work in any account of ethical agency that places habit at its core:

'Mountain peaks do not float unsupported; they do not even just rest upon the earth. They are the earth in one of its manifest operations. It is the business of those who are concerned with the theory of the earth, geographers and geologists, to make this fact evident, in its various implications. The theorist who would deal philosophically with fine art has a like task to accomplish'. ${ }^{25}$

Whether it be for fine arts or for ethics, the task of the philosopher is to explain how both fine arts and ethics are the outcome of what we -nature's inhabitants- do; how they are made possible by habits, both reflective and unreflective, and practices disturbing the latter and engendering new instances of fine art and ethical values, which in turn foster new habits etc. This sort of naturalism entails that -to quote Leiter, himself referring to the type of naturalism endorsed by McDowell:

' $[T]$ here is no special problem (from the standpoint of a naturalistic world view) about the epistemic or ontological status of the facts [including ethical

\footnotetext{
${ }^{24}$ Hans Fink, 'Three Sorts of Naturalism' (2006) 14 European Journal of Philosophy 202217.

25 J. Dewey, Art as experience (Capricorn Books 1958) 3.
} 
values] whose existence depends on these responsive capacities [naturally developed by human beings]'. ${ }^{26}$

While I wholeheartedly endorse the perspective encapsulated in the above rendering of McDowell's naturalism, Leiter thinks the latter does not qualify as 'naturalism', for it 'rejects the Naturalistic Conception of objectivity. ${ }^{27}$ This dismissal is worth unpacking, and to do that one must start with what that "special problem" which Leiter refers to in the above quote might consist in. Far from Modern ${ }^{28}$, that problem goes hand in hand with a drive to confine the natural to that which is the result of elementary, material forces (as opposed to human forces). Such a restrictive understanding of nature inevitably throws into sharp focus the ontological and epistemological precariousness of the man-made. ${ }^{29}$

Now one may resist the conclusion that this apparent precariousness is at all problematic based on at least two different strategies. The first one consists in arguing that what depends on human beings' responsive capacities is no-less real or objective than the natural, albeit in a different way. Quineans will necessarily be suspicious of such a line of argument, at least in so far as it presupposes ontological pluralism. $^{30}$

Another way of debunking the supposed 'special problem' about the epistemic and ontological status of the man-made consists in pointing out that the latter's precariousness only springs up in contrast to a peculiarly -and suspiciously- bare Nature. Not only is it far from clear whether such a Nature stripped bare of the

\footnotetext{
${ }^{26}$ Brian Leiter, Naturalizing jurisprudence: Essays on American legal realism and naturalism in legal philosophy (Oxford University Press 2007) 243.

27 ibid.

${ }^{28}$ It plays a central role in Plato's endeavour to capture the tension inherent in physis in Laws Book X.

${ }^{29}$ The "man-made" is broadly understood, and ranges from the ethical to the artistic, via the religious.

${ }^{30}$ Price usefully defines ontological pluralism (in his attempt at rescuing some of Carnap's insights) as the view according to which: "to the extent that different frameworks [at play in language] are independent, and doing different jobs, their existential quantifiers also seem to be doing different jobs-each framework seems to bring with it its own notion of reality." (Huw Price, 'Carnap, Quine, and the Fate of Metaphysics' (1997) 5 Electronic Journal of Analytic Philosophy 6).
} 
human touch is in fact available to us; quite why we would want to hanker after a concept of nature that reduces so drastically the explanatory resources at our disposal warrants an explanation. The latter goes hand in hand with one's conception of science.

\subsection{2. 'Science'}

When Leiter reminds us that, in contrast to outdated scientific models 'usually drawn from some idealized version of physics', 'scientific accounts of social phenomena have room, in principle, for hermeneutic concepts ${ }^{\prime 31}$, his naturalism seems resolutely un- 'bald'. The latter term is McDowell's, and 'bald naturalism' has been given various definitions, among which the view according to which 'reality is exhausted by the natural world, in the sense of the world as the natural sciences are capable of revealing it to us'. ${ }^{32}$

Yet Leiter's way of engaging with the arguments levelled by McDowell against bald naturalism seems to pull him back the other way. When he notes that, as a 'Quinean', it `all looks very strange [to him]' when McDowell questions the 'reason to suppose that natural science has a foundational status in philosophical reflection about truth - that there can be no facts other than those that would figure in a scientific understanding of the world ${ }^{33}$, Leiter could have simply gone on to point out that McDowell seems to assume the outdated, unduly narrow understanding of natural sciences alluded to above. Leiter's retorting instead that 'to simply push the scientific epistemology aside opens the ontological floodgates to a whole pre-

\footnotetext{
${ }^{31}$ Even if it 'does not show that they [do] make room for the kinds of Hermeneutic Concepts to which conceptual jurisprudents are attached'. Leiter, Naturalizing jurisprudence: Essays on American legal realism and naturalism in legal philosophy.

32 John McDowell, 'Projection and truth in ethics', Mind, value and reality (Mind, value and reality, Harvard University Press 1998).

${ }^{33}$ Ibid.
} 
Enlightenment conception of the world ${ }^{34}$ may lead the reader to assume that there is but one understanding of science capable of securing the 'ontological floodgates'.

The latter assumption is worth debunking, for it contributes to the growing popularity of a reductive materialist tradition whose influence is increasingly felt in some neuroscientific studies of moral agency. ${ }^{35}$ If the mind is but a by-product of matter, ${ }^{36}$ if our memories, beliefs and moral, political and aesthetic judgments are all aptly understood as physical states caused by nerve impulses in the brain, then most 'social scientific' accounts of the latter would need to be dismissed as ontologically queer.

In contrast, the conception of science presupposed by a habit-centred naturalism not only includes but gives a central role to 'humanistic' contributions. ${ }^{37}$ Among the many challenges which such a conception of science may usefully tackle, the following instigated the present article: the challenge of seeking to grasp what enables us to periodically stand against commonly accepted values to initiate change in the way we think of (and, ultimately, implement) the standards governing our way

\footnotetext{
${ }^{34}$ Leiter, Naturalizing jurisprudence: Essays on American legal realism and naturalism in legal philosophy.

${ }^{35}$ See for instance Greene's endeavour to 'send the soul packing for good', which proceeds on the assumption that our 'moral business' can and should be seen as a brain process and nothing more: 'What we [social neuroscientists] really want, I think, is to see the mind's clockwork [...] to truly, deeply believe that we are machines, we must see the clockwork in action. We've all heard that the soul is dead. Now we want to see the body [...] if the soul is not in the moral judgment business, it's not in any business at all. And, thus, what it would take to send the soul packing for good is a purely physical account of how the human mind does its moral business'. (Joshua D. Greene, 'Social neuroscience and the soul's last stand' in Alexander B. Todorov, Susan T. Fiske and Deborah A. Prentice (eds), Social neuroscience : toward understanding the underpinnings of the social mind (Social neuroscience : toward understanding the underpinnings of the social mind, Oxford University Press 2011) 264). For some vibrant criticism of the reductive materialism at play in the above quotation, see Raymond Tallis, Aping Mankind: Neuromania, Darwinitis and the Misrepresentation of Humanity (Acumen 2011) 359.

36 "There is only one sort of stuff, namely matter - the physical stuff of physics, chemistry, and physiology - and the mind is somehow nothing but a physical phenomenon. In short, the mind is the brain" (Daniel C Dennett, Consciousness explained (Penguin UK 1993) 33).

${ }^{37}$ Far from threatening the 'ontological floodgates', contributions from our social sciences and humanities are deemed essential to illuminating that which depends on human beings' 'responsive capacities', whether it be intentionality, action or moral judgments. As that which systematically enables all these responsive capacities, habit constitutes an apt focal point for the concept of science that underlies the type of naturalism defended here.
} 
of living together. Gaining a better understanding of the many ways of having a habit (and the mechanisms underlying both habit acquisition and habit metamorphosis) is crucial to the above, and both empirical investigations and philosophical analyses can contribute to it. While the former are still few and far between ${ }^{38}$ (though I am hoping to remedy this ${ }^{39}$ ), the latter have benefited from renewed interest in recent years.

\subsubsection{Naturalism and Internalism about reasons}

Renewed philosophical interest in habit could be said to stem at least in part from its playing a crucial role in any attempt to reconcile naturalism on one hand and internalism about reasons on the other hand, two positions that are traditionally deemed incompatible. Indeed it is because of this supposed incompatibility that many naturalists (including Leiter ${ }^{40}$ ) end up falling back upon a subjectivist position, whereby moral propositions refer to the attitudes of people, rather than objective facts independent of human opinion. This expressivism resolves a difficulty that is inherent in bald versions of naturalism. The latter (mistakenly) assume that the 'ontological cleansing' demanded by naturalism's rejection of dualist metaphysics leaves those attempting to explain how moral judgments reliably motivate us with only brute 'inert' facts as explanatory resources at their disposal.

The challenge faced by such bald versions of naturalism then consists in explaining how such facts -and the beliefs they give rise to- reliably motivate us to act in certain

\footnotetext{
${ }^{38}$ Experimental studies will have to overcome the difficulty in replicating a habitual setting in its full depth while large-scale ecological studies will struggle to isolate the relevant factors. On habit acquisition, see Phillippa Lally and others, 'How are habits formed: modelling habit formation in the real world' (2010) 40 European Journal of Social Psychology 998.

${ }^{39}$ An in-progress study replicates a routine professional situation in a highly immersive virtual environment. The study aims to grasp the impact of professional habituation (and expertise) on ethical awareness (forthcoming in 2017).

40 . Of course, the NeoHumean naturalist has not explained real normativity, as Scanlon complains, because real normativity does not exist: that is the entire upshot of the naturalist view. There are no reasons whose existence and character is independent of human attitudes; there are only human attitudes which lead us to 'talk the talk' of reasons. And if real normativity does not exist, if only feelings of inclination and aversion, compulsion and avoidance, actually exist, then that means that all purportedly normative disputes bottom out not in reasons but in the clash of will or affect.' Brian Leiter, 'Normativity For Naturalists' (2015) 25 Philosophical Issues 6474.
} 
ways (for most of our factual beliefs typically do not). Far from having only inert facts at its disposal, the naturalism defended here relies on habit to explain the reliable connection between moral judgment and motivation. The term reliable indicates a 'relaxed'41 approach to drawing a connection between moral judgment and motivation that relies on the fact that 'most of us are creatures of the right sort'. The latter expression is Railton's, but unlike Railton I do not take the possibility of an absence of such connection in pathological cases (such as the chronically depressive person Railton refers to) to invalidate internalism about reasons.

Railton's argument works like this: In order to `permit plausible connections to be drawn between, on the one hand, what is good or right and, on the other, what characteristically would motivate individuals who are prepared to submit themselves to relevant sorts of scrutiny ${ }^{42}$, the naturalist may usefully compare two types of practices: the practice of belief-based, everyday conversation and moral practice. Drawing upon Grice's ${ }^{43}$ 'complex theory of how the norms that govern conversational exchanges -internalized by speakers as mutually understood intentions to be cooperative in communicating- make it possible for what we literally say to one another to convey spoken and unspoken information ${ }^{44}$, Railton ventures:

'Might something like this be true in the case of moral language? Can a moral factualist argue that the 'normatively loaded', dynamic character of moral thought and practice is attributable to the joint operation of an encompassing framework of individual and shared norms, dispositions, and

\footnotetext{
${ }^{41}$ James Lenman, 'Moral Naturalism', The Stanford Encyclopedia of Philosophy (The Stanford Encyclopedia of Philosophy, 2006).

42 Peter Railton, Facts, values, and norms: Essays toward a morality of consequence (Cambridge University Press 2003) 33.

${ }^{43}$ P. Grice, Studies in the Ways of Words (Harvard University Press 1989).

${ }^{44}$ Peter Railton, 'Moral factualism' (2006) Contemporary debates in moral theory 201209.
} 
intentions, on the one hand, and the particular factual content of moral statements, on the other? ${ }^{\prime 45}$

In the 'joint operation' described by Railton, habit ${ }^{46}$ plays a central role, for it is habit that presides over the process of internalisation of the norms that condition the possibility of both moral practices and belief-based, everyday conversations. On such an account, a philosophically minded, self-proclaimed 'amoralist' who demands that we give her a reason to be moral is either incoherent ${ }^{47}$ or suffers from an impaired capacity to engage emotionally with her surroundings. The likelihood of a gap between sincere moral judgment and actual motivational engagement in the latter, pathological case ${ }^{48}$ does not detract from the fact that most human beings are creatures of the right sort. We do take an interest in natural facts about moral rightness, because the process of growing up involves developing a sensibility 'that includes not only ordinary cognitive and sensory capacities but also a motivating attitude - a capacity to find certain things simply "to be done". It would follow that those who master moral concepts will, when making moral judgments, have a tendency to act and feel accordingly. ${ }^{49}$

\footnotetext{
45 'This would permit the factualist to link moral judgment and motivation while providing the most straightforward explanation of how moral judgment could be logically and linguistically integral with 'ordinary factual' judgment, possessing all the marks of truth.' ibid.

${ }^{46}$ While Railton does not delve much into habit, he comes close to it in his description of 'our capacity for such nonpropositional, bodily centered, grounded mental maps and expectations', thanks to which 'we are able to connect human propositional thought to the world via de re and de se beliefs and intentions.' (Peter Railton, 'The Affective Dog and Its Rational Tale: Intuition and Attunement' (2014) 124 Ethics 813 838).

${ }^{47}$ One may argue that without habits we would not be able to speak of 'ourselves' at all: 'Isn't this the answer to the question 'what are we?' We are habits, nothing but habits - the habit of saying 'I'. Perhaps there is no more striking answer to the problem of the self.' (Gilles Deleuze, Empiricism and Subjectivity: an essay on Hume's theory of human nature (Columbia University Press 1991) x). ${ }^{48}$ Railton proposes the examples of Brad, who suffers from depression, and Theresa, whose 'capacities for empathy and engagement on a universal scale are quite limited' (Railton, 'Moral factualism').

${ }^{49}$ Ibid. Note that, in this quote, Railton is referring to McDowell's 'internalist' naturalism, which Railton is distancing himself from (unnecessarily, in my opinion) because of the possibility of the pathological cases mentioned above. The optimistic, Neo-Humean position defended here finds an echo in Mikhail's work on so-called 'universal moral grammar': 'Initial evidence for UMG comes from multiple sources, including psychology, linguistics, anthropology and cognitive neuroscience. Although none of this evidence is univocal or conclusive, collectively it provides at least modest support for the hypothesis that humans possess an innate moral faculty that is analogous, in some respects, to the
} 
Now, the element that conditions the success of such an 'internalist naturalism' -i.e. the process of gradual construction of one's ethical sensibility through habituation (or 'Bildung')- is also the source of its key challenge. For it is one thing to account for the way in which we may build our ethical sensibility (and moral competency) through upbringing, and another to explain how, given this dependency on the socio-cultural world we inhabit, we can nevertheless preserve an ability to stand against commonly accepted norms and challenge routine perceptions. This challenge is unpacked in the next section.

\subsection{What enables us to stand back from habit?}

Referring to Aristotle's account of how ethical character is formed, McDowell describes the process (which he calls 'Bildung') whereby 'human beings are intelligibly initiated into this stretch of the space of reasons by ethical upbringing, which instills the appropriate shape into their lives. The resulting habits of thought and action are second nature'. ${ }^{50}$ Clearly, the 'habits of thought and action' McDowell refers to in the above passage must be of a very different kind from those deemed by Kant to belong firmly to the 'messy', causal, space of desires, inclinations and the like? Or are they?

The success of McDowell's non-reductive naturalism, its potential to develop a narrative that takes us from human beings with needs and desires ('the sphere of causes') to internalized standards of right and wrong hinges upon a key ambiguity inherent in the concept of habit. Seizing upon this ambiguity, Bill Pollard endeavours to clarify 'how the same idea of habit can both occupy the space of causes and, at

language faculty that has been postulated by Chomsky and other linguists.' ( J. Mikhail, 'Universal moral grammar: theory, evidence and the future' (2007) 11 Trends Cogn Sci 143).

${ }^{50}$ John McDowell, Mind and world: with a new introduction by the author (Harvard University Press 1996) 84. 
least potentially, be a constituent of second nature ${ }^{51}$ by distinguishing between 'two ways of having the same habit' (rather than between different kinds of habit ${ }^{52}$ ).

Unlike the 'way which is available to pre-rational humans and other non-rational animals' the way 'available to humans once they have acquired the capacity to act for reasons' involves the capacity to (here I quote McDowell) 'contemplate alternatives; [and] step back from the natural impulse and direct critical scrutiny at $\mathrm{it}^{\prime}{ }^{53}$ Now this emphasis on critical scrutiny and stepping back from natural impulses may sound strangely reminiscent of the Kantian accounts of moral development referred to earlier. The difference -and it is crucial- lies in what is taken to enable this capacity to step back, i.e. whether the emotional, instinctive and habitual are taken to contribute at all to this ability. The challenge for any naturalist account of moral development consists in explaining how one grows within, rather than 'out' of the habitual.

This challenge is made all the more compelling since a naturalist methodology forbids any reference to some Archimedean point (whether it be Platonic forms, 'natural' values or a-priori principles), reference to which could somehow be trusted to wake us to the ignobility of some of our social practices. If all we have to trigger the movement of critical scrutiny (which McDowell refers to in the above quote) are our socially conditioned emotions and 'habits of evaluation', then to nevertheless postulate the capacity to contemplate alternatives to the habitual as central to our second nature sounds optimistic at best. What would trigger such contemplation? Emotions? Not if they are themselves dulled by habit:

'If habit causes feelings to decline, presumably to the point of expiration, then how is the role of emotional response-whether as a character trait; as

\footnotetext{
${ }^{51}$ Bill Pollard, 'Naturalizing the space of reasons' (2005) 13 International Journal of philosophical Studies 6976.

${ }^{52}$ As '[a]voiding talk of kinds of habit allows us to see how they can persist throughout the Bildung process' ibid.

${ }^{53}$ McDowell, 'Two sorts of naturalism'.
} 
the pleasure and pain accompanying virtuous and vicious acts; or as a motivational factor in action - to be accommodated?'. ${ }^{54}$

An Aristotelian account of excellence in the moral sphere would stress that situationspecific discernment is all we need to keep habits at the service of our ethical life. A lot hangs on whether such discernment is conceptualised as responsiveness to `affordances ${ }^{\prime 55}$ or, whether, like McDowell, one insists on tying adequate unreflective action to responsiveness to reasons. ${ }^{56}$ While broadly in agreement with McDowell in his Aristotelian analysis of the unreflective actions constitutive of habit, Dreyfus notes:
'McDowell concludes that, [...t] thanks to our inculcation into our culture, we become sensitive to reasons, which then influence our 'habits of thought and action'. One can easily accept that in learning to be wise we learn to follow general reasons as guides to acting appropriately. But it does not follow that, once we have gotten past the learning phase, these reasons in the form of habits still influence our wise actions' ${ }^{57}$

This quotation indirectly hints at a normative challenge which neither Dreyfus nor McDowell have explicitly engaged with: for most of us (the phronimos excepted), our 'habits of thought and action’ will be apt at generating their own `self-sustaining reasons'. How does one build into one's account of adequate unreflective action the necessary capacity to challenge such 'self-sustaining reasons' and maintain the

\footnotetext{
${ }^{54}$ Carlisle, 'Between Freedom and Necessity : Felix Ravaisson on Habit and the Moral Life'.

55 'Affordances are possibilities for action offered by the environment'. For full developments see $\mathrm{E}$. Rietveld, 'Situated Normativity: The Normative Aspect of Embodied Cognition in Unreflective Action' (2008) 117 Mind 973.

${ }^{56}$ Rietveld rightly emphasizes that 'unlike responsiveness to normative significance, responsiveness to reasons is not experienced by us in unreflective action. That makes 'responsiveness to reasons' an abstract, theory-dependent and potentially misleading term`. Rietveld goes on to wonder whether McDowells' insistence on tying adequate unreflective action to responsiveness to reasons stems from his 'fear that without a role for conceptuality we would not be able to place unreflective action in the category called space of reasons, being rather forced to see it as determined by disenchanted causal interaction.' (Erik Rietveld, 'McDowell and Dreyfus on Unreflective Action' (2010) 53 Inquiry 183 185). ${ }^{57}$ Hubert L Dreyfus, Overcoming the myth of the mental: how philosophers can profit from the phenomenology of everyday expertise (American Philosophical Association 2005) 50.
} 
'discernment' that conditions our availability to the ethical demands that may emerge from novel situations?

Pollard emphasises the importance of the agent's 'capacity to opt out [of habit] for reasons' but, just like McDowell, does not delve into exactly what underlies this capacity 'to adopt strategies to break habits' ${ }^{58}$. Pollard's focus is on delineating that subset of habitual actions which can be deemed 'rational': '[t]hat subset will consist of those habitual actions which cohere with the agent's worldview' ${ }^{59}$

'And that in turn will be enough to rule out nail-biting and cigarette smoking when they are against the agent's better judgement. These actions are not justifiable in the right sense. ${ }^{60}$

But will it be enough to rule out habits generated by frequent repetition of abhorrent practices (that were initially perceived as such)? When societal norms are perverted enough to condone the worst atrocities, an agent's worldview might well be malleable enough to accommodate -in some cases encourage- habits that one could not possibly deem to be 'rational'. The following quote is an excerpt from the diary of Kretschmer, a German pharmacist who joined the Nazi party in $1939^{61}$ and served in a Sonderkommando that took part in mass executions:

'As I said, I am in a very gloomy mood. I must pull myself out of it. The sight of the dead (including women and children) is not very cheering. But we are fighting this war for the survival or non-survival of our people. [...] If it weren't for the stupid thoughts about what we are doing in this country, the

\footnotetext{
${ }^{58}$ Bill Pollard, 'Habitual actions' in Timothy O'Connor and Constantine Sandis (eds), A companion to the philophy of action (A companion to the philophy of action, Blackwell 2010) 79.

59 ' $[T]$ his world view will consist of her beliefs, interests, projects and preferences, any any other items which disclose how the world is for her.' Pollard, 'Naturalizing the space of reasons'. 60 Ibid.

${ }^{61}$ Kretschmer was rejected by the SS for 'failure to satisfy requirements during a course on ideology' (Klee et al. 1991, 296, quoted in Herlinde Pauer-Studer and J. David Velleman, 'Distortions of Normativity' (2011) 14 Ethical theory and moral practice 329 on p. 348).
} 
Einsatz here would be wonderful, since it has put me in a position where I can support you all very well. Since, as I already wrote to you, I consider the last Einsatz to be justified and indeed approve of the consequences it had, the phrase: 'stupid thoughts' is not strictly accurate. Rather it is a weakness not to be able to stand the sight of dead people; the best way of overcoming it is to do it more often. Then it becomes a habit. ${ }^{62}$

To find oneself in a situation where one can deliberately choose to make a particular type of behaviour habitual (through systematic repetition) is uncommon; particularly so, one would hope, when the behaviour in question amounts to mass murder. ${ }^{63}$ Kretschmer's deliberate repetition strategy may or may not succeed in engendering a -murderous- habit. That success will in part be determined by the intensity of the emotions that are to be dulled by repetition. Assuming Kretschmer does contract the desired habit, is he in principle capable of 'opting out of it for reasons'? Absolutely. Would these reasons be found in his 'worldview', in the 'beliefs, interests, projects and preferences, and any other items which disclose how the world is for [him] $?^{64}$ Not necessarily. In fact, given the extent to which the success of the Nazi regime relied upon a deep internalisation of a perverted worldview, it is quite unlikely.

Where, then, does Kretschmer -or anybody who has contracted any morally significant habit- find the momentum necessary to stand back and question it? 'If I am nothing but self, there is no way of transcending myself; if I am nothing but habit, there is no way of liberation through my own actions. ${ }^{65}$ Given the ongoing process of conditioning that dynamically shapes the self, Carlisle suggests `a version of Nietzsche's idea of 'eternal recurrence' as a kind of ethical test: do you will this

\footnotetext{
62 Ibid.

${ }^{63}$ Carlisle notes that Ravaisson gives little thought to the 'bad habits' to which our natural inclinations can lead: 'he writes of grace but not of sin; of desire for the good but not of perversity' (Carlisle, 'Between Freedom and Necessity : Felix Ravaisson on Habit and the Moral Life').

${ }^{64}$ Pollard, 'Naturalizing the space of reasons'.

${ }^{65}$ Carlisle 2006, p. 32.
} 
action to be repeated indefinitely? Do you will this action to become a habit? Do you will to become this self? ${ }^{66}$

The second-person formulation of the above ethical test suggests that it is up to a third person to ask those questions, to confront us with the habits we have contracted and the extent to which they are conducive to our idea of self. The more this idea is fixed, rigidified by some overarching religious, ideological or moral discourse, the more out of reach the words -or mere presence- of others become. ${ }^{67}$ Because they bypass the need to articulate what it is about us constantly evolving human beings that calls for doing things in a particular way, the dualist presuppositions underlying such discourses afford a fixed framework that defines the self's relationship to others. This fixed relationship in turn encourages the rigidification of the habits that are constitutive of that relationship, including the habits of thought and action that underlie a legal system. That the latter is enabled by -and enables- our habits is forgotten. Instead of coming to terms with the contingency -and responsibility- inherent in its being a social artifact, law is presented as a necessity (natural or otherwise), thus minimising the impact of criticisms and calls for change.

Hart expresses precisely this concern (even though he does not frame it in terms of habits -see next section) when he highlights a fundamental point of intersection between Bentham and Marx, who both:

'agreed on two fundamental points which are relevant to my present theme: first, that their tasks as social thinkers were to clear men's minds as to the

\footnotetext{
${ }^{66}$ Carlisle, 'Creatures of habit: the problem and the practice of liberation' (my emphasis).

${ }^{67}$ It may well be that, when it comes to awakening us from deeply entrenched habits, 'mere' words are no match for the kind of encounter described in radical terms by Levinas when he refers to the 'face of the Other' summoning each and every one of us. Calling for humility and openness to the unforeseen, Levinas' ethics is built upon empathetic imagination, a 'wisdom that still learns from every new human face'. Emmanuel Levinas, Totality and infinity: an essay on exteriority (Duquesne University Press 1969). When it comes to awakening us from habits, such encounters may be metaphorical. It may be facilitated by a piece of art, or the reading of a great novel.
} 
true character of human society, and, secondly, that human society and its legal structure which had worked so much human misery, had been protected from criticism by myths, mysteries and illusions, not all of them intentionally generated, yet all of them profitable to interested parties. [...] For both of them such mystery was made possible by the failure on the part of ordinary men to realise that the forms of law and human society were at bottom merely human artefacts, not natural necessities but things actually made by men, and hence things which could be unmade and remade. ${ }^{68}$

When Hart bemoans the fact that an established legal system is particularly conducive to a society that is 'deplorably sheeplike' -and where the sheep might all end up in the slaughterhouse ${ }^{69}$, he is referring to a concern expressed in different terms from those used in the above quote. For it is not so much the progressive disregard for the responsibility (and possibilities) entailed by the fact that law is 'unmade and remade' by us that Hart emphasises, but rather the disenfranchisement made possible by the fact that, in an established legal system, only 'officials' need accept the Rule of Recognition.

\section{From legal institutions to the political monotony of rigidified habits (and the risk of a sheeplike society)}

The aim of the previous section was to highlight the extent to which one's understanding of habit reflects one's meta-ethical understanding of agency. If autonomy is taken to require transcending one's causal environment (so as to leave a 'safe' distance between that environment and one's normative choices), then habits belong firmly to the province of sociology. They may be of interest to the

\footnotetext{
${ }^{68}$ H. L. A. Hart, 'Bentham and the Demystification of the Law' (1973) 36 Mod L Rev 26.

${ }^{69}$ Hart, The concept of law.
} 
moral or political philosopher only to the extent that they constitute a threat to personal autonomy.

Alternatively, one may dismiss the conceptual relevance of habits to our understanding of law because, as Shapiro puts it bluntly: 'habits are not normative activities'. Given 'the normative nature of legal activity', asserting any form of conceptual link between law and habits would fall foul of 'Hume's challenge', supposedly forbidding any 'derivation of an ought from an is'. ${ }^{70}$ Aside from the fact that it is far from clear whether Hume is rightly understood to forbid such a 'derivation' (Putnam convincingly argues otherwise ${ }^{71}$ ), taking Hume's interdict as seriously as Shapiro does considerably reduces the explanatory resources at one's disposal when it comes to grasping the nature of the institutional facts" ${ }^{72}$ that shape and enable our legal system.

On a (non-reductive) naturalist understanding of ethical agency, habits not only condition but enable normative choices. Therefore, they raise a considerable challenge for the moral or political philosopher: given that slowly acquired habits of evaluation - 'all the whirl of organism Wittgenstein calls 'forms of life'73-are all we have got to trigger the movement of scrutiny necessary to questioning commonly accepted practices, how does one preserve the possibility of civic responsibility?

Hart openly acknowledged the fostering of such civic responsibility as a 'moral task' guiding his theory. Significantly though, he felt unable to reconcile that concern with a (non-reductive) naturalist methodology. Hart stuck instead to an agnostic meta-

\footnotetext{
${ }^{70}$ Scott J. Shapiro, Legality (Harvard University Press 2011) 2615 (loc.).

71 'The logical positivist fact/ value dichotomy was defended on the basis of a narrowly scientistic picture of what a 'fact' might be, just as the Humean ancestor of that distinction was defended upon the basis of a narrow empiricist psychology of ideas' and impressions'. The realization that so much of our descriptive language is a living counterexample to both (classical empiricist and logical positivist) pictures of the realm of ' fact' ought to shake the confidence of anyone who supposes that there is a notion of fact that contrasts neatly and absolutely with the notion of 'value' supposedly invoked in talk of the nature of all 'value judgments' (Hilary Putnam, The collapse of the fact/value dichotomy and other essays (Harvard University Press 2002) 26).

72 In contrast, see John R Searle, The construction of social reality (Simon and Schuster 1995).

${ }^{73}$ McDowell, 'Non-cognitivism and rule following'.
} 
ethical position (for want of a better solution to his meta-ethical dilemma ${ }^{74}$ ) and only considered habits to better oppose them to rule-governed practices. This need not have been so.

The next section (2.1) highlights Hart's intellectual affinities for what could have been a (non-reductive) naturalist account of legal normativity, whereby there would be no 'gap' between habits as social facts on the one hand and social rules on the other: a gap which Hart endeavours to bridge via his notion of acceptance. Section 2.2 outlines the two-way relationship between law and habits, with a particular focus on the different types of habits law may foster. Section 2.3 then proceeds to show how such a naturalist narrative bolsters Hart's claim that law is inherently conducive to a society that is 'deplorably sheeplike' (once this claim is rid of its association with 'official acceptance').

\subsection{Hart's intellectual affinities for a (non-reductive) naturalist account of legal normativity.}

Far from assuming that habits are not worthy of philosophical inquiry, Hart notes in a book review published in 1952:

'What makes behavior intelligent (or stupid) is its relation to the agent's needs or purpose.[...] For the purpose of his analysis Mr. Holloway [...] exhibits the intelligent response not as a sharp break from habit but as a development and refinement of it. Few philosophers, I think, could fail to benefit from this examination of the intelligent versus stupid dichotomy and of the connection between human intelligence, too often portrayed in absolute and splendid isolation, and habit equipment. ${ }^{75}$

\footnotetext{
${ }^{74}$ I have outlined in detail this dilemma, and Hart's agnostic way out in Sylvie Delacroix, 'Meta-ethical agnosticism in legal theory: mapping a way out' (2010) 1 Jurisprudence 225.

${ }^{75}$ H. L. A. Hart, 'Signs and Words' (1952) 2 The Philosophical Quarterly 5959.
} 
The Concept of Law's scant developments on habit (and its relationship to law's normative force) may have proceeded in part from didactic concerns: to admit that habits can be had with some degree of reflexivity might have muddled the otherwise rather neat distinction between rule and habit. It may also have had a lot to do with Hart's efforts to dispel Austin's 'habit of obedience' framework and 'free the concept of a rule from confusion with the concepts of a command or a habit'. ${ }^{76}$ Beyond (and behind) these factors, I believe Hart may have been in the grip of a meta-ethical dilemma that just did not allow for a naturalist account of normativity despite his otherwise clear inclinations in that direction.

A non-reductive naturalist account of legal normativity needs to go from human beings with needs, desires and -most importantly- habits to a fully-fledged normative framework (one expressed in 'oughts', 'musts' and 'shoulds') without any 'intervention of the divine spark, or gifts from unexplained quarters' ${ }^{77}$ Hart was almost there ${ }^{78}$-had he allowed himself to delve further into the relationship between the practices that are constitutive of social norms and the habits that often underlie them. There were at least two familiar intellectual paths available to him.

\subsubsection{The Wittgensteinian take on 'custom'}

Given his explicit reliance on Wittgenstein's Philosophical Investigations, Hart could have chosen to expand upon the latter's reference to 'custom' as a way of explaining how the causal processes constitutive of habit get to acquire the significance they do when they evolve into rule-following practices:

'Then can whatever I do be brought into accord with the rule?' --- Let me ask this: what has the expression of a rule -say a sign-post - got to do with my actions?

\footnotetext{
${ }^{76}$ Herbert Lionel Adolphus Hart, 'Analytical Jurisprudence in Mid-Twentieth Century: A Reply to Professor Bodenheimer' (1956) 105 U Pa L Rev 953958.

${ }^{77}$ Blackburn, 'Normativity a la mode'.

${ }^{78}$ Hart's account of legal normativity is developed at length in Sylvie Delacroix, 'Hart's and Kelsen's conceptions of normativity contrasted' (2004) 17 Ratio luris 501.
} 
What sort of connection is there here? Well, perhaps this one: I have been trained to react to this sign in a particular way, and now I do so react.

But this is only to give a causal connexion, only to explain how it has come about that we now go by the sign-post; not what this going-by-the-sign really consists in. On the contrary, I have further indicated that a person goes by a signpost only in so far as there exists a regular use of sign-posts, a custom. ${ }^{79}$

Wittgenstein's focus is to show that rule-following's 'bedrock' is 'simply what we do': 'If I have exhausted the justifications I have reached bedrock, and my spade is turned. Then I am inclined to say: 'This is simply what I do". ${ }^{80}$ This upstream focus, going from rule-following practices back to patterns of behaviour, means that Wittgenstein is not particularly preoccupied with the factors that enable changes in rule-following practices. Yet that is arguably the most tricky aspect of naturalist accounts of rule-following (see section 1.2.2). For one needs to articulate the degree of reflexivity needed for such changes, without betraying the key naturalist insight: that any such reflexivity is necessarily embedded in, and conditioned by, the 'bedrock' of causal connections that are constitutive of 'custom'.

\subsubsection{The Weberian narrative}

Alternatively, Hart could have developed a narrative along Weberian lines (even if he denied it, we know that Hart carefully read Weber's Economy and Society ${ }^{81}$ ). The key challenge would then consist in articulating a narrative that builds upon Weber's typology of social relationships. Such a narrative would set forth a continuum from forms of social relationship based on 'usage' (Brauch) and 'custom' (Sitte) ${ }^{82}$, via what

\footnotetext{
${ }^{79}$ Ludwig Wittgenstein, Philosophical Investigations (Blackwell 1958) para. 198.

80 lbid.

${ }^{81}$ In her biography of H.L.A Hart, Nicola Lacey highlights Hart's apparent (but unacknowledged) indebtedness to Weber's sociology. Nicola Lacey, The nightmare and the noble dream: A life of HLA Hart (Oxford: Oxford University Press 2004).

${ }^{82} \mathrm{~A}$ uniformity in social action is a usage in so far as the probability of its existence within a group is based on nothing but actual practice' (Max Weber, Economy and society, an oultine of interpretive
} 
Weber calls 'conventions', all the way to a legal order, as a convention backed by a group of people deemed to have the duty (and legitimacy) to apply sanctions against those who transgress the law. A distinctive feature of the latter consists in the fact that the subjective attitudes of the participating individuals are directed towards the belief in a legitimate order'. ${ }^{83}$ With striking similarities to Hart's internal point of view, Weber illustrates the attitudes he mentions with the following example:

'[W]hen a civil servant appears in his office daily at a fixed time, he does not act only on the basis of custom or self-interest which he could disregard if he wanted to; as a rule, his action is also determined by the validity of an order (viz., the civil service rules), which he fulfills partly because disobedience would be disadvantageous to him but also because its violation would be abhorrent to his sense of duty (of course, in varying degrees) ${ }^{84}$

Far from a one-way evolutionary story that would identify forms of social order based on usage or custom as 'primitive', such a narrative would remain true to Weber's insights only if it managed to articulate the dynamic relationship between each form of social order. ${ }^{85}$ In particular, Giddens highlights the fact that a legal order not only builds upon usage and custom, but also facilitates the emergence of new forms of usage and custom:

'There is no clear empirical line between usage and custom, and what Weber calls 'convention'. Conformity is not, in this case, a matter of the voluntary disposition of the individual. [...] The empirical relationship between custom, convention and law is an intimate one. Even the hold of sheer usage may be very strong. Those who frame laws to cover conduct which was formerly

sociology (University of California Press 1978) vol.1). A custom is a usage which has been established for a long time.

${ }^{83}$ Anthony Giddens, Capitalism and modern social theory: An analysis of the writings of Marx, Durkheim and Max Weber (Cambridge University Press 1971) 154.

${ }^{84}$ Weber, Economy and society, an oultine of interpretive sociology.

${ }^{85}$ In most empirical cases, elements from each form of social order will not only co-exist but 'dynamically' facilitate (or hinder) their respective development. 
merely 'usual' frequently discover that very little additional conformity to the prescription in question is attained. However, usage and custom do in most cases provide the origin of rules which become laws. The reverse also occurs, although less frequently: the introduction of a new law may eventuate in new modes of habitual conduct. ${ }^{86}$

The next section (2.2) outlines the two-way relationship between law and habits, with a particular focus on the 'reverse' movement described above.

\subsection{From patterns of behaviour to legal norms, via (reflective) habits and / or practices - and back.}

The diagram below outlines a continuum that stretches from collective patterns of behaviour all the way to legal norms, via habits and / or practices. Practices (whether they can be characterised as 'reflective habits' or not) stem from collective patterns of behaviour, and they presuppose a reflective awareness of the needs or purposes served by those patterns of behaviour, with a concomitant ability to change those patterns in light of those needs or purposes. Those practices that are not reflective habits distinguish themselves from the latter by their genesis, which presupposes some deliberative agency ${ }^{87}$ all the way through. Most legal philosophers who have sought to capture the way in which the foundations of law are social practices have been influenced either by Bratman's 'shared cooperative activity' model or by Lewis' 'coordination convention' model. ${ }^{88}$ These models have in common the fact that they

\footnotetext{
${ }^{86}$ Giddens, Capitalism and modern social theory: An analysis of the writings of Marx, Durkheim and Max Weber.

87 'We exercise deliberative agency when we deliberate or reflect on what we ought to do, attempting to evaluate our reasons for action in the light of our values, convictions, and beliefs about the world. This kind of agency has rightly impressed philosophers-largely, we suspect, because deliberative agency seems to be uniquely human-but in fact only a small proportion of our actions involve much in the way of deliberation or reflection.' (N. Levy and T. Bayne, 'Doing without deliberation: automatism, automaticity, and moral accountability' (2004) 16 Int Rev Psychiatry 209).

${ }^{88}$ Bratman, 'Shared cooperative activity'; David K. Lewis, Convention: a philosophical study (Harvard University Press 1963).
} 
require both 'commitment to conceptual and epistemic agreement' ${ }^{89}$ and `strong practical commitment'. Matthew Smith highlights the significance of such assumptions and raises important doubts about the extent to which such 'hypercommital' models are apt at conceptualising the bulk of social practices at the root of law's institutional structure.

What matters, for our purposes, is to debunk the dominant (and intellectualist) assumption that the social practices giving rise to law must presuppose some deliberative agency all the way through (or route ' 3 ' in the diagram below). Not only are these types of social practices unlikely to account for the vast majority of those social processes that give rise to law; such exclusive focus on this narrow type of social practices has also hindered our chances of constructing a rich understanding of legal normativity. For only by building (reflective) habits into the continuum that leads from patterns of behaviour to legal norms can we account for the role played by law's institutional structure in fostering the return movements described in '7' and ' 8 ' below (as well as the normative implications flowing from ' 9 '). Before unpacking these in the next section, defining each of the vectors in the diagram below provides an opportunity for a neat summary of our discussion so far:

\footnotetext{
${ }^{89}$. W $]$ hat is required for shared intention and shared action is not only that there is conceptual agreement with respect to concepts deployed with respect to the activity to be shared but that the agents have more or less correct beliefs about each other's subplans and intentions' (Matthew Noah Smith, 'The Law as a Social Practice Are Shared Activities at the Foundations of Law?' (2006) 12 Legal Theory 265 282). While I find Smith's arguments in relation to Bratman's theory of shared cooperative activities convincing, I am less sure that his arguments apply equally well to Lewis' analysis of conventions.
} 


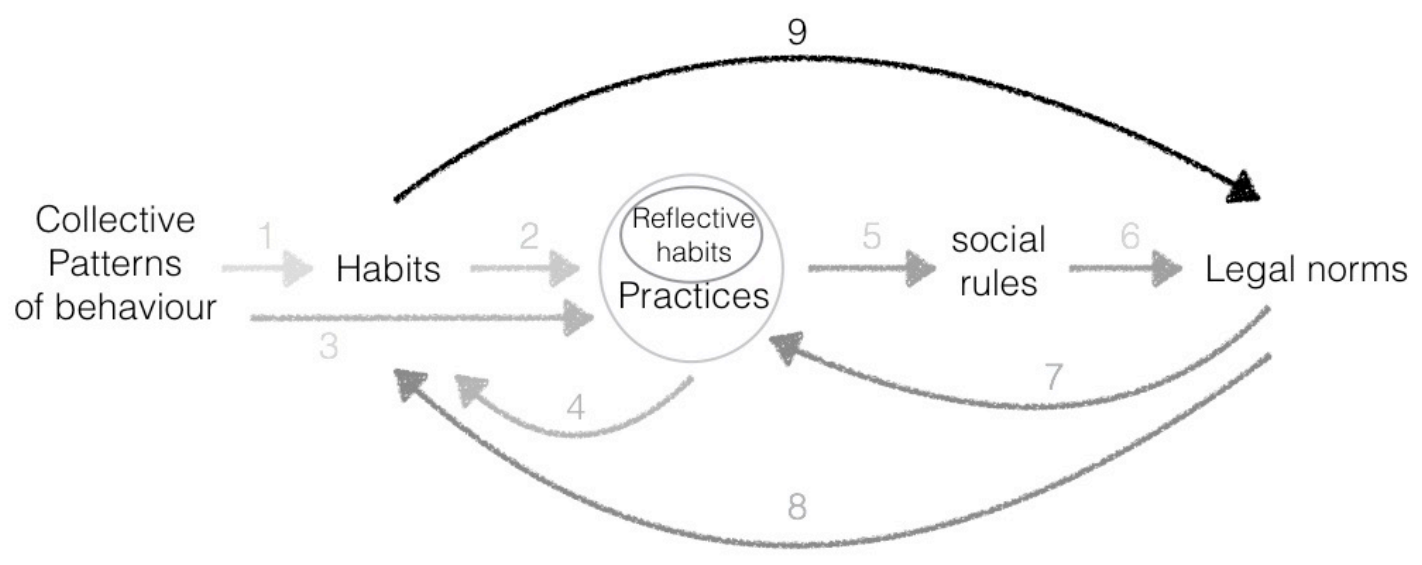

'1': The repetition of a particular pattern of behaviour leads to its becoming automatic on the part of those in whom a habit has taken hold. Such automaticity is concomitant with a reduction in the awareness of behaving in that particular way. ${ }^{90}$

'2': A reflective habit requires some critical distanciation from the internalised pattern of behaviour, which is evaluated in the light of the needs or purposes of the agent(s).

'3': A practice can emerge out of a shared commitment or endeavour to do something together, without having to involve any degree of automatic agency. ${ }^{91}$

\footnotetext{
${ }^{90}$. The paradigm of such behaviour is the over-learned action. One is usually (fully) conscious when performing an over-learned action, but one is not conscious of the over- learned action itself.' (Levy and Bayne, 'Doing without deliberation: automatism, automaticity, and moral accountability'). ${ }^{91}$ Levy and Bayne helpfully distinguish between automatic agency ('Automatic agency involves an absence-or at least a reduction - of the experience of doing ') and automatistic agency, within which they distinguish between global automatisms and local automatisms: 'Global automatisms involve a global disruption of consciousness; they occur in the context of somnambulism [etc.] Individuals in
} 
This way of conceptualising the genesis of social practices -which need not make any reference to habit- has dominated legal theory so far, in part thanks to the considerable influence of both Bratman's and Lewis' theories.

'4': With repetition, a practice may come to be internalised in a way that gives rise to the type of automatic agency characteristic of habit, yet without the goal-oriented adaptability and critical distanciation associated with reflective habits.

'5': The values associated with some practice lead to peer-pressure to conform and widespread social condemnation of any deviation from that practice, thus marking the emergence of a social rule.

'6': An institutional structure is built to support the continuous adaptation, implementation and adjudication of such social rules.

'7': Some legal norms or institutions give rise to novel practices, some of which may disrupt a community's habits of thought (or behaviour).

'8': Other legal norms or institutions prompt widespread disengagement from social / community issues that would otherwise have triggered reflective practices within that community.

'9': In some cases, those in charge of continuously adapting and generating legal norms in a particular domain are so alienated ${ }^{92}$ from the institution they serve (and the values that institution promotes) that they are able to contribute to the modification of the applicable legal regime in that domain without any deliberative engagement on their part.

these states perform fairly complex actions in a 'robotic' manner. Their environmental awareness is limited [...] What we call 'local automatisms', by contrast, involve only a disruption of consciousness and control over a particular kind of action. A person with a local automatism is fully conscious, but they experience no sense of agency over a particular complex and apparently voluntary action.' (ibid.). ${ }^{92}$ Smith, 'The Law as a Social Practice Are Shared Activities at the Foundations of Law?'. 
The next section (2.3) unpacks the 'moral risk' inherent in the development of law's institutional structure notably by referring to the 'return movement' encapsulated in ' 8 ' (in contrast to ' 7 '), and the type of alienation that may result from it.

\title{
2.3. Laws' inherent moral risk and the types of habits law may foster
}

\begin{abstract}
'Without law, social order requires considerable buy-in from the general population: The people are regulated by norms that are more or less accepted. [...] With the emergence of law, however, people are also regulated by norms that meet officials' criteria of validity and are enforced by specialized agencies. This division of labor can alienate people from the most important rules that govern their lives - rules that threaten to become remote, technical, and arcane. That is one more reason why the rule of law is not an unqualified human good: It is in the nature of law to pose such risks, and the rule of law cannot eliminate them. ${ }^{93}$
\end{abstract}

Building upon Hart's own analysis of the 'risks' concomitant with the emergence of institutionalized rules ${ }^{94}$, Leslie Green proceeds to argue that the moral import of such risks (inherent in the very nature of law) disproves Hart's separability thesis. ${ }^{95}$ Perhaps because of his focus on the latter, Green does not dwell on how exactly people get 'alienated [...] from the most important rules that govern their lives', save for referring to Hart's own (unfortunate) phrasing in terms of acceptance: 'where

\footnotetext{
${ }^{93}$ Green, 'Positivism and the Inseparability of Law and Morals'.

94 'The step from the simple form of society [...] into the legal world [...] brings its solid gains at a certain cost. The gains are those of adaptability to change, certainty and efficiency, and these are immense; the cost is the risk that the centrally organised power may well be used for the oppression of numbers with whose support it can dispense, in a way that the simpler regime of primary rules could not' (Hart, The concept of law).

${ }^{95}$ As it 'marks a connection between law and morality of a reverse kind' (Green, 'Positivism and the Inseparability of Law and Morals').
} 
there is a union of primary and secondary rules [...] the acceptance of the rules as common standards for the group may be split off from the relatively passive matter of the ordinary individual acquiescing in the rules by obeying them for his part alone $^{\prime 96}$ (in a pre-legal society, by contrast, acceptance of the rules has to be widespread).

Wilkinson voices doubts as to 'whether widespread acceptance can be said to preclude the vice of alienation, if acceptance is given no further specification' ${ }^{97}$ Given the minimalist way in which Hart defines it (acceptance may be based on `an unreflecting inherited or traditional attitude, or the mere wish to do as others $\mathrm{do}^{\prime 98}$ ), acceptance is certainly no safeguard against the 'sheeplike' predicament Hart worries about. To make sense of the type of engagement that may make a ‘slaughterhouse' ending less likely, one must look at the opposite of such engagement, and unpack the exact nature of the alienation that is claimed to be an endemic risk concomitant with the emergence of law's institutional structure.

Among the 'five variants of alienation' described by Melvin Seeman, 'powerlessness' encapsulates one aspect of the alienation we are concerned with: in its Marxian origins, alienation referred to the extent to which the prerogative and means of decision are expropriated [from the worker] by the ruling entrepreneurs' ${ }^{99}$ Extended beyond the industrial sphere by Weber, this type of alienation aptly captures the way in which the transition from a customary order to a fully-fledged legal structure may be said to take away from most 'the prerogative and means' of shaping a legal landscape that is not deemed to be 'theirs' anymore. This aspect of alienation ties in with what Hart bemoaned as 'the failure on the part of ordinary men to realise that the forms of law and human society were at bottom merely

\footnotetext{
${ }^{96}$ Hart, The concept of law.

${ }^{97}$ Michael A. Wilkinson, 'Is Law Morally Risky? Alienation, Acceptance and Hart's Concept of Law' (2010) 30 Oxford Journal of Legal Studies 441451.

${ }^{98}$ Hart, The concept of law.

${ }^{99}$ Melvin Seeman, 'On the meaning of alienation' (1959) American sociological review 783784.
} 
human artefacts, not natural necessities but things actually made by men, and hence things which could be unmade and remade. ${ }^{100}$

Yet today that failure to come to terms with our role (and responsibility) as authors of those very practices that can ultimately give rise to law stems at least in part from another variant of alienation. It is one that is connected -but not reducible to- what Seeman describes as 'meaninglessness':

'This second type of alienation, then, refers to the individual's sense of understanding the events in which he is engaged. We may speak of high alienation, in the meaninglessness usage, when the individual is unclear as to what he ought to believe -when the individual's minimal standards for clarity in decision-making are not met. ${ }^{101}$

As a society evolves from a tight-knit, small community, the number and complexity of the issues to be addressed to continually seek (better) ways of living together is daunting - and the 'minimal standards for clarity in decision-making' mentioned above are arguably rarely met. Legal institutions are designed to tackle such complexity. Freeing the individual from the task of balancing a complex set of reasons, law is to mediate between its subjects and the reasons that apply to them. ${ }^{102}$ The 'secondary rules' that come with legal institutions establish how legal change may occur. Relinquishing responsibility for this fundamental aspect of 'normative labour' comes at a price, for it is all too tempting to relax and enjoy the benefits of institutional authority (rather than actively partake in the 'normative labour' facilitated by such institutions).

\footnotetext{
${ }^{100}$ Hart, 'Bentham and the Demystification of the Law'.

${ }^{101}$ Seeman, 'On the meaning of alienation'.

102 'The advantage of normally proceeding through the mediation of rules is enormous. It enables a person to consider and form an opinion on the general aspects of recurrent situations in advance of their occurrence. It enables a person to achieve results which can be achieved only through an advance commitment to a whole series of actions, rather than by case to case examination'. Joseph Raz, The morality of freedom (Clarendon Press 1986) 58.
} 
Raz vividly captures those benefits in his 'service conception of authority': when law succeeds in its claim to authority, it is supposed to give us reasons for action that replace the set of dependent reasons, and thus simplify our practical reasoning. To a large extent the efficiency of a legal system depends on this 'de-mobilisation' of practical reasoning - and its concomitant fostering of habituated behavior. But of course there is another side to Raz's theory. Law's claim to authority is to succeed only if it is legitimate. So we are not meant to relax for too long. We are supposed to keep checking that law still has a `sufficiently high normal justification score' ${ }^{103}$, i.e. that it does better enable us to comply with the demands of 'right reason'. ${ }^{104}$ In so doing, the hope is that we may, to use Wilkinson's phrase, 'reclaim law's authority'. ${ }^{105}$

The worry is that, in practice, fewer and fewer of us will bother; that more and more of us will surrender to the comfort of demobilised practical reasoning. If trusting in legal institutions to have figured out the right course of action in particular circumstances was initially a choice (that may be born out of necessity), that trust can become so habitual as to forget itself - and the possibility of an alternative. This aspect of alienation -'meaninglessness'- is connected to the 'powerlessness' aspect discussed earlier:

"[I]n some important degree, the view that one lives in an intelligible world may be a prerequisite to expectancies for control; and the unintelligibility of

\footnotetext{
${ }^{103}$ Emran Mian, 'The curious case of exclusionary reasons' (2002) 15 Canadian Journal of Law and Jurisprudence 99107.

104 . In such cases conformity with the underlying reasons is secured by complying with the rule, or rather a better degree of conformity than can otherwise be achieved is so obtained. This can justify complying with the rule even when it requires action which the underlying reasons do not. Such compliance may still be the best strategy to maximise conformity with the underlying reasons'. Joseph Raz, Practical Reason and Norms (rev. ed, with postscript edn, Princeton University Press 1990) 194.

105 'Contrary to Raz's image of law as an official authority, in the modern democratic order we are all implicit 'mouthpieces' of the law, an insistence on which might begin to inculcate a sense of legal and social responsibility and perhaps in more radical guise, a social purpose, to reclaim law's authority.' (Wilkinson, 'Is Law Morally Risky? Alienation, Acceptance and Hart's Concept of Law').
} 
complex affairs is presumably conducive to the development of high expectancies for external control (that is, high powerlessness), ${ }^{106}$

In our context, estrangement from the political and social practices that empower each and every one of us to shape our legal landscape may be said to stem at least in part from resignation in the face of that landscape's sheer complexity. This resignation in turn allows for one's retrenchment to habitual frames of thought, uncritically adopting whatever legal framework is applicable, as described in vector ' 8 ' in the diagram discussed in 2.2 .

At this stage the distinction between different ways of having a habit developed in section 1.2. becomes particularly relevant. For it may well be that what is distinctively alienating about a legal regime is not so much the possibility of nonacceptance, but rather the way in which a legal system is conducive to the development of rigid, unreflective habits. Unlike the goal-oriented (hence adaptable) habits that give rise to legal practice, the rigid habits which are facilitated by the emergence of a legal system are formed on the back of the legal system's institutionalized adaptation to change.

In a pre-legal world, by contrast, people are regulated by norms that have no particular origin in the enactment of an individual or an institution ${ }^{107}$ : they find their origin in a pattern of collective behavior that acquires particular significance in light of the purpose it has come to be associated with. While it is habitual in nature, that pattern of behavior cannot give rise to the kind of practice constitutive of a legal system unless it is capable of adapting to changing aspirations. In the absence of a 'secondary rule' establishing how legal change occurs, such change can only happen organically. People don't 'accept' but rather 'live by' the norms they need to foster a better way of living together. That aspiration in turn generates a practice whose perceived social value may call for this practice's institutionalisation.

\footnotetext{
${ }^{106}$ Seeman, 'On the meaning of alienation'.

${ }^{107}$ Marmor, 'Legal conventionalism', 194.
} 
The trouble is that legal institutions - because of the division of normative labour they enable- encourage a shift towards widespread passivity, or what one may deem a 'leisurely' attitude ${ }^{108}$ towards our norm-making (and norm-sustaining) practices. de Tocqueville anticipates this shift in his prescient analysis of America's nascent democracy:

'Thus, the ruling power, having taken each citizen one by one into its powerful grasp and having molded him to its own liking, spreads its arms over the whole of society, covering the surface of social life with a network of petty, complicated, detailed, and uniform rules [...] It does not break men's wills but it does soften, bend, and control them; rarely does it force men to act but it constantly opposes what actions they perform; it does not destroy the start of anything but it stands in its way; it does not tyrannize but it inhibits, represses, drains, snuffs out, dulls so much effort that finally it reduces each nation to nothing more than a flock of timid and hardworking animals with the government as shepherd'. ${ }^{109}$

Leslie Green has a wonderfully naturalist way of summing things up: 'A bit like unstable isotopes, political institutions have standard patterns of decay that are explained by the nature of the thing that is decaying'. ${ }^{110}$ Hart's insight (in line with de Tocqueville's) was to highlight the extent to which legal institutions are inherently conducive to what he called 'sheeplike' behavior. Had he delved further into the mutually enabling relationship between law and habit, he might have been able to substantiate this insight in a way in which his reference to the possibility of non-

\footnotetext{
108 It [the immense and protective power that stands above men] provides their security, anticipates and guarantees their needs, supplies their pleasures, directs their principal concerns, manages their industry, regulates their estates, divides their inheritances. Why can it not remove from them entirely the bother of thinking and the troubles of life? Thus, it reduces daily the value and frequency of the exercise of free choice; it restricts the activity of free will within a narrower range and gradually removes autonomy itself from each citizen.' Alexis de Tocqueville, Democracy in America (Penguin 2003) 805.

109 Ibid.

${ }^{110}$ Green, 'Positivism and the Inseparability of Law and Morals'.
} 
acceptance could not. Despite his affinities for a non-reductive, naturalist account of legal normativity, Hart's insistence on analyzing the 'step into the legal world' by reference, instead, to an overly cognitive notion of 'acceptance' betrays the appeal of an entrenched dualist and intellectualised conception of agency. ${ }^{111}$

\section{Conclusion}

Ever since Hart's swift critique of Austin (introducing the 'internal point of view' to distinguish rules from mere habits), legal theory has mostly proceeded on the assumption that any account of the normativity of law must be deliberative all the way through: to let habits impinge upon such an account would fall foul of 'Hume's law' and sabotage the lot. This assumption reflects a dualism whose hold on contemporary legal theory is concomitant with a one-sided view of habit: in its negative (rather than enabling) aspect, habit is indeed what can stand in the way of our living up to our responsibility as normative animals. This responsibility stems from the characteristically human capacity to occupy the 'space of reasons', which in turn enables us to see how the world can be made better, to make normative claims that will guide our moral or political agenda. For those in thrall to this metaphor of two spaces, it is the very possibility of our normative freedom -no less- that hangs on those two spaces being kept distinct.

On a non-reductive naturalist understanding of ethical agency, accounting for our normative freedom is no less important. Only the challenge concomitant with such an explanation is greater. For one cannot count on any 'gap' between spaces to explain what enables us to step back and confront commonly accepted practices to declare them wanting. To understand what conditions the possibility of such reflexive scrutiny, attention must be paid to what typically hampers it: habit.

\footnotetext{
${ }^{111}$ For a candid, contemporary, formulation of such a dualist framework applied to Hart's internal point of view, see: Veronica Rodriguez-Blanco, 'Peter Winch and HLA Hart: Two Concepts of the Internal Point of View' (2007) 20 Canadian Journal of Law \& Jurisprudence 45313.
} 
That's all very well, some legal theorists might say, but what's in it for jurisprudence's endeavor to grasp the nature of law? Doesn't the realm of law start precisely where habit ends? This article's answer to such skepticism is twofold. Conceptually speaking, a theory of law that dismisses the importance of habits ends up with a poorer concept of ethical agency and a concomitantly truncated account of legal normativity.

From a normative perspective, an account of the two-way relationship between law and habit is crucial to grasping the danger inherent in law's particular institutional structure. Because (and to the extent that) such a structure institutionalizes mechanisms for change and successfully simplifies our practical reasoning in relation to key societal concerns, we may inadvertently find ourselves enjoying ever-longer normative holidays. What if our ability to adopt a reflective stance towards our habits is compromised by the lack of 'normative exercise' induced by such holidays? The continuum that goes from collective patterns of behaviour all the way to legal norms via habits and practices -and back- would be compromised. The legal structure would mostly foster sheeplike, unreflective habits. Not only are such habits incapable of generating the type of practices giving rise to (novel) legal structures. Such unreflective habits are also all too easily exploited by unscrupulous shepherds bent on a 'slaughterhouse' ending, to use Hart's metaphor. 
